\title{
Securitisation of Migration at the EU level after Paris' Attacks: The Response of the European Public
}

\author{
Dionysios Stivas \\ Hong Kong Baptist University \\ stivasd@life.hkbu.edu.hk
}

\begin{abstract}
By applying the Copenhagen School's securitisation theory, this paper assesses the extent to which immigration has been securitised at the EU level after the 2015 Paris attacks. It is doing so by not only examining the presence of the securitisation actors and the security speech acts, as is commonly done in the current securitisation literature, but also by analysing from a legal point of view, two emergency measures implemented by the EU to deal with the migration crisis. Most importantly, this paper investigates the response of the European public to the securitisation moves and highlights that this aspect of the Copenhagen School's analytical framework has been not only undertheorised but also understudied.
\end{abstract}

Keywords: Audience Acceptance, European Union, Migration, Securitisation, Security, Terrorism

"I cannot bear and will not accept an amalgamation of the topics of refugees and terrorism in the wake of the atrocious attacks in Paris. The cynics who exploit the suffering of Paris have not understood that those who perpetrated the attacks are precisely those whom the refugees are trying to flee."

Jean Claude Juncker, President of the European Commission, 21/11/2015

\section{Introduction}

Drawing on the Copenhagen School's securitisation theory, this paper examines the extent to which the EU refugee crisis has been securitised at the EU level. The literature that addressed this issue before 2015 claimed that immigration has not been securitised. Yet, in 2015, Europe dealt with one of the largest influx of refugees ever recorded in the European history and with the unprecedented surge of terrorist incidents on the European continent. The series of terrorist attacks, commencing in Paris in November 2015, and the attempts of certain influential political figures across Europe to connect these tragedies with the refugee crisis facilitated the securitisation of migration. That is one of the reasons that triggered the conduct of this study. The second reason is the identification of a gap in the securitisation literature. Buzan, Wæver, and de Wilde, in their seminal study Security: a new framework for analysis (1998) argue that securitisation occurs when a securitising actor claims that a particular referent object is existentially threatened. On the basis of this allegation, the securitising actor defends his right to utilise extraordinary measures for guaranteeing the survival of the referent object. According to Buzan, Wæver and de Wilde, three 
elements are necessary for a securitisation to be considered successful: 1) the designation of an existential threat to a referent object, 2) the adoption of emergency (and unlawful) measures, and 3) the acceptance by the audience. ${ }^{1}$ Despite Buzan, Wæver and de Wilde stressing the importance of the third element, audience acceptance, most of the securitisation scholars who employ the Copenhagen School of Security Studies analytical framework focus only on the 'securitisers' and the security rhetoric. Almost no one investigates the extent of the audience's acquiescence in the securitisation moves.

To establish whether the recent European refugee crisis has been successfully securitised this paper firstly establishes the links between migration, terrorism, and security. Then it turns to exploring the existence of the three securitisation components at the EU level. Who are the securitisation actors at the EU level? What sort of rhetoric do they utilise to transform the refugee crisis from a political to a security issue? What measures are taken to materialise the securitisation moves? Who is the target audience? Has this audience explicitly or implicitly approved the securitisation rhetoric and the adoption of the emergency and potentially unlawful measures? To provide answers to these questions, this paper explores the lawfulness of two of the most prominent responses by the EU for dealing with the refugee crisis. Subsequently, it assesses the response of the target audience to the securitisation moves. Considering that securitisation actors are usually political figures, it is inferred that their target audience is the European public. Therefore, surveys that investigate the 'feelings' of the Union's public about immigrants and the refugee crisis are investigated. The outcomes of these surveys shed light on whether migration has been securitised at the EU level after the 2015 terrorist attacks in Paris.

\section{Securitisation of Migration}

\section{A Migration-Terrorism-Security Nexus}

In the 'West', immigrants are often presented as threatening the economy, the 'Western lifestyle', and public order. ${ }^{2}$ Politicians across Europe exploit the public's anxiety of getting 'drowned' by the 'waves' of immigrants to weaponise immigration on the political agenda and approach it as a security issue. ${ }^{3}$ The majority of European citizens seem to agree with European politicians. ${ }^{4}$ The public considers that the sharp rise in the numbers of asylum seekers arrivals in Europe is directly related to the rise of crime, the fragmentation of social solidarity and collective identity, the poor performance of the labour market, low levels of education, and inter-ethnic tension. ${ }^{5}$

What is more, immigration has turned into a "burning existential question", due to its relationship with the "free movement of terrorists". ${ }^{6}$ Regularly, politicians, the mass

\footnotetext{
${ }^{1}$ Barry Buzan, Ole Waever, and Jaap de Wilde, Security a New Framework for Analysis, (Boulder, Colo.: Lynne Rienner, 1998), 24- 26.

${ }^{2}$ Georgios Karyotis and Dimitris Skleparis, "Resistance to the Criminalization of Migration" in The Immigrant Other: Lived Experiences in a Transnational World, eds. Rich Furman, Greg Lamphear and Douglas Epps (New York, NY: Columbia University Press, 2016), 266.

${ }^{3}$ Ioan Bogdan, Maria Claudia Mera, and Florin Ioan Oroian, "Determinations and Conditionality in the Context of the Migration in the European Union," Eurolimes 18, (2014):117.

${ }^{4}$ Elena-Ana Nechita and Nicolaie Iancu, "Debates and Controversies on European Migration Policies," Law

Review 8, no. 2 (December 2018): 4.

${ }^{5}$ Ibid.

${ }^{6}$ Jef Huysmans, The Politics of Insecurity: Fear, Migration and Asylum in the EU (London, UK: Routledge, 2006), 64.
} 
media and the EU public frame the refugees as responsible for the recent terrorist attacks. They claim that potential terrorists may easily pretend to be asylum seekers and in that way reach the heart of Europe to execute their deadly plans. ${ }^{7}$ The likelihood of terrorists utilising the refugees' influx as a 'trojan horse' to enter Europe provides politicians with a pretext for the adoption of stricter measures of migration control ${ }^{8}$ or even for the securitisation of migration. To assess the extent to which the refugee crisis has been succesfully securitised at the EU level, the Copenhagen School of Security Studies' analytical framework seems to be the most appropriate.

\section{B Securitisation Theory}

The first researchers who attempted to comprehensively explain and define securitisation were scholars from the Copenhagen School of Security Studies (Copenhagen School). Buzan, Wæver and de Wilde (1998) argued that "we are witnessing a case of securitization" when "by means of an argument about the priority of an existential threat the securitizing actor [manages] to break free of procedures or rules he should otherwise be bound by". ${ }^{9}$ To further facilitate the study of a securitisation process, the Copenhagen School's theorists outlined three components (or steps) of a successful securitisation: (1) existential threats, (2) emergency action, and (3) the effects on inter-unit relations by breaking free of rules. ${ }^{10}$ By inter-unit relations they meant the relationship between the securitising actor and the audience. "...only once an actor has convinced an audience (inter-unit relations) of its legitimate need to go beyond otherwise binding rules and regulations (emergency mode) can we identify a case of securitization", the Copenhagen School's scholars claimed. ${ }^{11}$ Although the three components of a successful securitisation seem to be of equal importance, the literature on securitisation focuses mainly on studying the designation of existential threats. Usually, the securitising actors designate existential threats to a referent object by issuing a statement, making a speech or giving an interview. The designations of existential threats are also called security speech acts. ${ }^{12}$

Anyone could be a securitising actor and articulate security speech acts. But not everybody's statements could activate the adoption of extraordinary measures. The political elites, due to the wide coverage of their statements by the mass media and because of their ability to transform declarations into actual measures are usually placed in the position of the securitising actor. ${ }^{13}$ However, no securitisation could be successfully performed without the political elites having managed to persuade their target audience. Securitisation is the 'outcome' of a process through which agents (political elites) and audiences (the public) share the same knowledge about the alleged significance of a threat and a common 'understanding' about the urgency for the deployment of all 'available resources' to prevent this threat from being further developed. ${ }^{14}$ The acceptance of the security speech act by the audience is "a

\footnotetext{
${ }^{7}$ Fiona B. Adamson, “Crossing Borders: International Migration and National Security,” International Security 3 , no. 1, (Summer 2006): 175 .

${ }^{8}$ Christina Boswell, "Migration Control in Europe after 9/11: Explaining the Absence of Securitization," Journal of Common Market Studies 45, no. 3 (2007): 590.

${ }^{9}$ Buzan, Wæver, and de Wilde, Security, 25.

${ }^{10}$ Ibid. 26.

${ }^{11}$ Rita Taureck, "Securitization Theory and Securitization Studies," Journal of International Relations and Development 9, (2006): 55 .

${ }^{12}$ Buzan, Wæver, and de Wilde, 33 and 40.

${ }^{13}$ Ibid. 40.

${ }^{14}$ George Karyotis, "Securitization of Migration in Greece: Process, Motives and Implications," International Political Sociology 6, (2012): 391.
} 
precondition for the legitimization of measures that go beyond the daily routines, the elevation of the issue in the agenda, and the violation of the rules". ${ }^{15}$ The securitisation process is dependent on an "empowering audience" that legitimises and reproduces the actors' securitising frame. ${ }^{16}$ It is the audience that is the ultimate judge of the securitising move. ${ }^{17}$

Although the role of the audience has been emphasised by numerous scholars it has been examined insufficiently in the current literature. Buzan, Wæver and de Wilde warned that "one danger of phrases securitization and speech act is that too much focus can be placed on the acting side, thus privileging the powerful while marginalizing those who are the audience and judge of the act" ${ }^{18}$ Obviously, securitisation theory places undue emphasis on the discourse of the political elites but does not "consider the popular discourse in which securitization moves are embedded". ${ }^{19}$ The existing literature mainly employs discourse analysis to assess securitisation. However, discourse analysis can only point towards the influence of a securitising actor without being able to gauge the impact of the security language on public threat perceptions. ${ }^{20}$ Despite the emphasis on the importance of the public, the audience acceptance element has remained unaddressed and understudied.

A proper study of the successful securitisation of a particular topic should highlight and assess the role of the audience. The recent refugee crisis and the reaction of the 'European audience' to the security speech acts at the European Union level seem to be the most appropriate case study.

\section{Methodology}

This study investigates the events that occurred between November 2015, when a series of terrorist attacks occurred in Paris, and December 2016. The reason this study focuses on this particular timeframe is twofold. First, until the Paris' attacks, officials across Europe and the European public expressed empathy towards the asylum seekers. In the aftermath of the terrorist attacks, the feelings of compassion changed. Immigration became a major cause of insecurity. Second, most of the studies investigating securitisation of migration in Europe were conducted before 2015. A detailed assessment of the securitisation of immigration at the EU level after the Paris' attacks would fill this temporal gap in the literature. In terms of data gathering and analysis, qualitative as well as quantitative methods of research are utilised. The first assesses the security speech acts and examines the securitisation measures while the latter investigates public surveys.

To come to a conclusion whether immigration has been securitised at the EU level, this study takes a pioneering approach by inspecting all components of the securitisation process: (1) designation of an existential threat, (2) adoption of emergency action(s),

\footnotetext{
${ }^{15}$ Çiğdem H. Benam, "Emergence of a "Big Brother” in Europe: Border Control and Securitization of Migration," Insight Turkey 13, no. 3 (2011): 194.

${ }^{16}$ Giuseppe Campesi, "The Arab Spring and the Crisis of the European Border Regime: Manufacturing Emergency in the Lampedusa Crisis," EUI Working Paper, RSCAS 2011/59, (2011): 3.

${ }^{17}$ Scott D. Watson, "Framing' the Copenhagen School: Integrating the Literature on Threat Construction," Millennium: Journal of International Studies 40, no. 2 (2011): 298.

${ }^{18}$ Buzan, Wæver, and de Wilde, Security, 41.

${ }^{19}$ Robert W. Glover, "The Theorist and the Practitioner: Linking the Securitization of Migration to Activist Counter-Narratives," Geopolitics, History and International Relations 3, no. 1 (2011): 94.

${ }^{20}$ Georgios Karyotis and Stratos Patrikios, "Religion, Securitization and Anti-immigration Attitudes: The Case of Greece," Journal of Peace Research 47, no. 1 (2010): 45.
} 
and most importantly, (3) acceptance by the target audience. Drawing on a scientific framework that utilises variables to measure, establish and/or define a case, the securitisation of immigration is the dependent variable. The independent variables are the three components outlined above. As illustrated in Table 1, if this study concludes that the EU officials present immigration as a security threat to the EU, that they couple their security speech acts with emergency and rules-violating measures and that the target audience accepts the security speech acts and the adopted measures, then we are dealing with a successful securitisation of immigration at the EU level. But if it is found that securitisation occurs despite the absence of one of the independent variables, it means that the absent variable does not play a significant role in the securitisation process. Securitisation is possible without it.

With regards to the level of analysis, this study focuses exclusively on the EU level. Securitising actors are actors who due to their social standing, influence and power, and public recognition may convey messages broadly, immediately and efficiently. At the EU level, some actors hold more power than others to designate existential threats. The actors most capable of securitising migration are the leaders of the EU's most prominent institutions. These are the European Council and the European Commission (Commission). The first, even though it does not adopt legally binding decisions, is qualified to designate the direction that the EU should take regarding particular issues. The latter, with its ability to draft laws and its oversight function, may propose the adoption of emergency measures and oversee their implementation. The statements and press releases of these EU institutions enjoy broad coverage by the mass media. Words, phrases, and sentences uttered by EU officials portraying migration as an existential threat constitute indications of potential securitisation attempts and are thoroughly analysed. The lawfulness of two of the most controversial measures that the European Union adopted to deal with the refugee crisis is investigated as well.

Table 1. Variables and Time Frame

\begin{tabular}{|c|c|c|c|c|}
\hline \multirow{5}{*}{$\begin{array}{c}\text { Independent } \\
\text { Variables }\end{array}$} & Designation of & European Council & \multirow{6}{*}{ 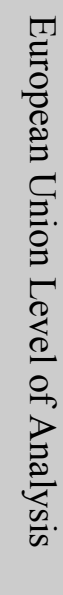 } & \multirow{6}{*}{ 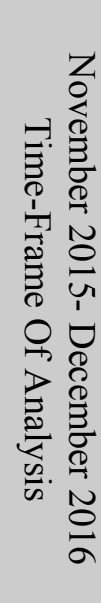 } \\
\hline & Adontion of Emeroency/ & ERCG A gency & & \\
\hline & 1110 gіtiा & EU-Turkey Statement & & \\
\hline & Acceptance by the & Eurobarometer & & \\
\hline & Target Audience & $\begin{array}{c}\text { Pew Research Centre } \\
\text { Surveys }\end{array}$ & & \\
\hline $\begin{array}{c}\text { Dependent } \\
\text { Variable }\end{array}$ & \multicolumn{2}{|c|}{ Successful Securitisation } & & \\
\hline
\end{tabular}

Source: Author's own construction

To assess the audience acceptance component of securitisation, this study firstly defines the target audience and secondly investigates the feelings of this audience towards immigrants and refugees. It does so in order to gauge the audience's potential response to the security speech acts and to the emergency measures. Assuming that the target audience is the European public and considering the vast size of the public 
and its linguistic, cultural and Inter-State differences, this study examines surveys that pose to the public questions about migration and that are publicly available.

\section{Designations of Existential Threats}

\section{A European Council}

Among the EU institutions, the European Council is the one that defines the political direction and priorities and sets the EU's policy agenda. Through its 'Conclusions', it highlights issues of concern and calls for actions. These 'Conclusions' are examined thoroughly to identify whether the refugee crisis has been presented as an existential threat.

From November 2015 onwards, migration held a prominent place among the issues discussed at the European Council summits. Regular references to "migration flows", "illegal migration", and "migration crisis" are observed in almost all the 'Conclusions'. However, the sentences that contain such words are very carefully phrased. They put emphasis on the safety of the migrants and respect of their human rights. The sections of the 'Conclusions' dedicated to internal security and terrorism are also carefully articulated to avoid any accidental references to migration therein. However, migration is directly mentioned in the parts of the 'Conclusions' referring to the necessity for the revision of the Schengen Border Code and the urgency for the operationalisation of the European Border Coast Guard Agency (EBCG). The migration sections of the 'Conclusions' highlight the need to reinforce the control of the EU's external borders to meet both migration and security objectives. ${ }^{21}$ The presence of migration and security within the same sentence demonstrates that for the European Council the two issues are interrelated. Yet, although migration has been framed as a security-relevant issue, it has not been presented as an existential threat to the Union. The European Council often reiterated the need for a comprehensive strategy "consistent with the right to seek asylum, fundamental rights, and international obligations". 22

\section{B The President of the European Council}

Frequently, the President of the European Council, Donald Tusk, associated migration with the security of the Union. The "urgency of the situation" and the requirement for "immediate additional operation measures" were emphasised in his official statements. ${ }^{23}$ In one instance, he combined the words "migration", "security" and "terrorism" within the same sentence. "The fact that millions of Europeans feel insecure is real. People [...] express fears over migration, terrorism [...]" Tusk underlined after a summit in Bratislava. ${ }^{24}$ Obviously, the combination of migration,

\footnotetext{
21 "European Council Meeting Conclusions," Press Release 28 June 2016, accessed 29 June 2017, http://www.consilium.europa.eu/en/press/press-releases/2016/o6/28-euco-conclusions/.

22 "European Council Meeting Conclusions," Press Release 15 October 2015, accessed 29 June 2017, http://www.consilium.europa.eu/media/21693/euco-conclusions-15102015.pdf.

23 "Invitation letter from President Donald Tusk to the EU heads of state or government before Malta summit," Press Release 31 January 2017, accessed 29 June 2017, http://www.consilium.europa.eu/en/press/pressreleases/2017/01/31-tusk-invitation-letter-malta/; "Remarks by President Donald Tusk at the informal summit in Malta," Press Release 3 February 2017, accessed 29 June 2017, http://www.consilium.europa.eu/en/press/pressreleases/2017/02/o3-tusk-press-remarks-malta/.

24 "Remarks by President Donald Tusk after the Bratislava Summit," Press Release 16 September 2016, accessed 29 June 2017, http://www.consilium.europa.eu/en/press/press-releases/2016/o9/16-tusk-final-remarksbratislava/.
} 
terrorism and security in the same sentence does not directly associate these words with each other. However, when the leading 'voice' of the European Union claims that migration is linked to Europeans feeling insecure, then the foundation for the securitisation of immigration could be set. Admitting that an issue constitutes a threat to a referent object is the first securitisation step. The next would be to announce the need to resort to extraordinary means and procedures to tackle the threat.

Tusk's inclination to securitise migration is even more apparent when he speaks to the mass media. In March 2016 he advised potential migrants to avoid coming to Europe. ${ }^{25}$ Despite his references to the commitments of the Union to the protection of human rights, he proposed more than once that it would be acceptable and legitimate to detain irregular migrants for up to 18 months for identification checks. ${ }^{26}$ In January 2016, he stated that the EU had "no more than two months to get things under control" regarding the migration crisis. ${ }^{27}$ Otherwise, "we will face grave consequences such as the collapse of Schengen". ${ }^{28}$ In another of his statements, he claimed that the future of Europe "is being threatened" by radical, populist, nationalistic sentiment that utilises the migration influx to increase its influence. ${ }^{29}$

The European Council seems to avoid connecting terrorism with migration and security in its official documents. However, the President of the European Council, in his official and unofficial statements, did not hold back from correlating migration with threats to the Union's security and calling for the adoption of urgent and forceful measures. Could these actions qualify as security speech acts? On the basis of the Copenhagen School's theorem, for the identification of a security speech act, it is the designation of existential threats and the adoption of extraordinary measures that matters. It is true that Tusk presented migration as a threat to the operationalisation of a core element of the EU integration, the Schengen system. Yet, the purpose of this statement was not to call for the adoption of extraordinary measures for dealing with the refugee crisis. Tusk merely desired to terminate the (lawful) emergency measures introduced by several Member States (re-initiation of border controls on a temporary basis) that threatened the existence of the Schengen area.

To conclude, despite the frequent references to migration and insecurity, the European Council seems to have avoided securitising migration. In no case has the European Council associated the refugee influx with the series of terrorist attacks across the European continent.

\section{European Commission}

Following the terrorist attacks of 2015, the most powerful official of the Commission, the President, Jean-Claude Juncker, attempted to eliminate any potential link between the refugee crisis and terrorism. "I will not accept an amalgamation of the topics of

\footnotetext{
25 Jennifer Rankin, "Do not come to Europe, Donald Tusk warns economic migrants," The Guardian, March 3, 2016, https://www.theguardian.com/world/2016/mar/o3/donald-tusk-economic-migrants-do-not-come-toeurope; Maïa de la Baume, "Donald Tusk says EU migration crisis is 'never-ending," Politico, April 13, 2016, http://www.politico.eu/article/donald-tusk-says-eu-migration-crisis-is-never-ending/.

${ }^{26}$ Eric Maurice, “Tusk: 'Wave of migrants too big not to be stopped,” EUobserver, December 3, 2015, https://euobserver.com/migration/131363.

${ }^{27}$ Eric Maurice, “Tusk sets EU two-month deadline on migrant crisis,” EUobserver, January 19, 2016, https://euobserver.com/migration/131905 accessed 29 June 2017.

${ }^{28}$ Ibid.

${ }^{29}$ Graig Winneker, “Tusk: EU needs ‘tough’ migration policies,” Politico, April 22, 2016,

http://www.politico.eu/article/donald-tusk-eu-needs-tough-migration-policies/.
} 
refugees and terrorism in the wake of the attacks in Paris. [...] Those who perpetrated the attacks are precisely whom the refugees are trying to flee" he warned. ${ }^{30}$ In the wake of the deadly truck-attack in Berlin in December 2016, Juncker reiterated that the best way to fight terror was with "openness" and stressed that Europe should continue to receive migrants. ${ }^{31}$ Likewise, Frans Timmermans, the first Vice President of the Commission, who coordinated a new policy on migration as one of the ten Commission priorities, backed Juncker's remarks about the necessity for maintaining an open borders policy. ${ }^{32}$ Dimitris Avramopoulos, the Commission's senior migration official, attempted to diffuse the anti-immigration sentiment by reminding Europeans that "anyone resisting the arrival of migrants should remember that Europe is an ageing continent and needs to attract new people, as well as develop strategies to send home those who enter illegally". ${ }^{33}$ Obviously, with their official statements, the key EU Commission officials highlighted the need to dissociate the refugee crisis from the terrorist attacks. The official communications of the Commission followed the same line. A detailed examination of the Commission's documents revealed this institution's human rights approach to the refugee crisis. ${ }^{34}$

To sum up, the EU's officials and institutions that had the power to designate the refugee crisis as a security threat and to propose, adopt and implement extraordinary measures at the EU level claimed that there was no connection between the refugees and the terrorist attacks. Yet, the same officials and institutions supported two particular EU emergency actions the operationalisation and conclusion of which have raised legal concerns. The following section investigates whether the establishment of the European Border Coast Guard (EBCG) and the conclusion of the EU-Turkey Statement violated any substantive and procedural EU rules and whether they constituted emergency, extraordinary (and unlawful) measures.

\section{The Legality of the EU Emergency Measures}

\section{A The European Border and Coast Guard Agency}

In the aftermath of the Paris attacks, the Commission urged the establishment of the EBCG Agency. The EU hoped that establishment of the agency would enable the EU to manage migration more efficiently, improve the internal security of the EU, and safeguard the principle of free movement of persons. ${ }^{35}$ To do so, for the first time in the history of the Union, the border control of the Member States would be entrusted

\footnotetext{
30 "Paris attacks: the European Union stands united," Press Release 16 November 2015, accessed 29 June 2017, http://europa.eu/rapid/press-release_AC-16-1970_en.htm.

${ }^{31}$ Virginia Hale, "EU chief: Borders must stay open despite deadly terror attacks," Breibart, December 24, 2016, http://www.breitbart.com/london/2016/12/24/eu-chief-borders-must-stay-open/.

${ }^{32}$ Will Worley, "Six out of 10 migrants to Europe come for 'economic reasons' and are not refugees, EU Vice President Frans Timmermans says,” Independent, January 27, 2016,

https://www.independent.co.uk/news/world/europe/six-out-of-10-migrants-to-europe-come-for-economicreasons-and-are-not-refugees-eu-vice-president-a6836306.html.

33 Tamsin Rutter, "EU risks being shaken apart by refugee crisis, warns Brussels," The Guardian, December 4, 2015, https://www.theguardian.com/public-leaders-network/2015/dec/o4/european-union-values-shakenrefugee-crisis.

34 "Back to Schengen: Commission proposes Roadmap for restoring fully functioning Schengen system," Press Release 4 March 2016, accessed 29 June 2017, http://europa.eu/rapid/press-release_IP-16-585_en.htm; "Commission recommends extending temporary internal border controls for a limited period of three months," Press Release 25 October 2016, accessed 29 June 2017, http://europa.eu/rapid/press-release_IP-163501_en.htm.

35 "A European Border and Coast Guard to protect Europe's External Borders," Press Release 15 December 2015, 29 June 2017, http://europa.eu/rapid/press-release_IP-15-6327_en.htm.
} 
(under certain circumstances) to an EU agency. For the Member States, the control of their external borders is a sensitive matter directly related to their sovereignty. It is very unlikely that any EU Member State would permit an EU agency to intervene within its borders without its consent as provided by the EBCG Regulation. Concerns, therefore, were raised regarding the legality of the EBCG Regulation and its compliance with all procedural rules during the deliberations for its adoption. ${ }^{36}$ The short period between the proposal by the Commission and the announcement of the EBCG agency's official launch raises even more concerns. A period of legislative deliberation of less than twelve months has been rarely observed in the EU's policymaking. By investigating the form of the legislative procedure that was followed in the adoption of the EBCG Regulation, its legal basis, as well as the text of the Regulation itself, I expect to shed light on these concerns.

The EBCG Regulation was adopted under the ordinary legislative procedure. The European Parliament (EP), directly elected by the EU citizens, and the Council of the EU (Council) that comprises representatives of the EU Member States have an equal say in this procedure. The Commission submits a legislative proposal to the EP and the Council, who must agree on the text via a series of readings for it to become EU law. For the adoption of the EBCG Regulation, the procedural rules seem to have been followed correctly. The EP and the Council consulted each other as usual and made use of their legitimate right to amend the Commission's proposal. The short timeframe it took for the adoption of the Regulation also does not seem unlawful. The European Council and the Commission emphasised the importance of dealing with the migration crisis immediately and efficiently. Admittedly, it is unusual for the EU to adopt Regulations in such a short timeframe (nine months). This, however, does not mean that a Regulation agreed in such a short time is unlawful. Yet, to come to a conclusion on the lawfulness of the Regulation, it is essential to examine its legal basis.

The Regulation is based on Article 77(2) (b) and (d) and Article 79 (2) (c) of the Treaty on the Functioning of the European Union (TFEU).$^{37}$ According to these provisions the EP and the Council acting in accordance with the ordinary legislative procedure shall adopt measures concerning the checks to which persons crossing external borders are subject, any measure necessary for the gradual establishment of an integrated management system for external borders, and measures in the areas of illegal migration and unauthorised residence, including removal and repatriation of those residing without authorisation. As noted above, the ordinary legislative procedure was followed as prescribed by the legal basis. However, a closer look at the text of the Regulation reveals some potential legal pitfalls. Article 1 of the Regulation includes in its 'subject matter' the assurance of a high level of internal security. Considering that EU internal security is covered by a different Treaty Chapter than the border policies, migration, and asylum part, and given that the legal basis of this Regulation covers merely the prevention and fight against illegal crossing and irregular migration, it seems like a legal basis issue could emerge. ${ }^{38}$ It seems like the adoption of measures for addressing internal security that are embedded in a legal instrument made for the protection of the external borders goes beyond the 'subject matter' of the Regulation.

\footnotetext{
${ }^{36}$ Sergio Carrera and Leonhard den Hertog, "A European Border and Coast Guard: What's in a name?” CEPS Paper in Liberty and Security in Europe, no. 88 (2016): 2; Francesca Ferraro and Emilio De Capitani, "The new European Border and Coast Guard: yet another "half way" EU reform?" ERA Forum 17, no. 3 (2016):1.

37 "Consolidated version of the Treaty on the Functioning of the European Union, 2008/C 115/01," European Union, 13 December 2007, accessed 29 June 2017, http://eur-lex.europa.eu/legalcontent/EN/TXT/?uri=OJ\%3AC\%3A20o8\%3A115\%3ATOC.

${ }^{38}$ Ferraro and Capitani, "The New European Border," 12.
} 
This indicates it may be just a matter of time until the Court of Justice of the EU will be called to adjudicate on this 'mission creep'. Until that happens, the EBCG Regulation may be considered as not having violated any rules. Yet, to tackle the perceived threat of the refugee crisis, the EU did not only propose and implement the EBCG but also endorsed and concluded a legally and politically controversial deal with Turkey.

\section{B EU-Turkey Statement}

Turkish and EU officials had been working on a draft plan to deal with refugees since $2015 \cdot{ }^{39}$ This resulted in the conclusion of a 'refugee deal' between the EU and Turkey. That 'deal' provided for the return of individuals arriving irregularly by boat in Greece to Turkey, in exchange for increased EU resettlement of Syrians from Turkey, large sums of aid to Turkey and the abolition of EU visa restrictions for Turkish nationals. ${ }^{40}$ The 'deal' was considered by many to be successful. Following its conclusion, the irregular arrivals decreased by $97 \% .{ }^{41}$ Yet, the 'deal' provoked serious concerns regarding its legality. Most of these concerns focus on the name of the 'deal'. ${ }^{42}$

Article 218 of the TFEU outlines the procedure that the EU should follow when negotiating and concluding agreements with third countries. Based on Article 218(6)(a)(v) TFEU, such agreements may only be concluded by the Council after obtaining the consent of the EP. In the case of the EU-Turkey Statement (Statement), the EP's consent was neither requested nor provided. To avoid the time consuming and potential negation with the EP, the Council used the term 'statement' to present its agreement with Turkey. Procedurally therefore, the 'Statement' seems to be questionable.

Usually, a 'Statement' does not have any legal impact, ${ }^{43}$ is not legally binding and does not require the approval from either the EP or the National Parliaments. ${ }^{44}$ Moreover, the fact that the vague term 'will' instead of the stronger 'shall' or 'should' is used throughout the text of the 'Statement' indicates the desire of its drafters to avoid bestowing it with legal enforceability. Usually, agreements under international law utilise the terms 'shall' and 'should' in their texts to outline obligations. ${ }^{45}$ In the EUTurkey Statement, both the text and the context contain elements of an international agreement. Commitments for both parties emerge from the points agreed. Both parties to the 'Statement' therefore intended to bind themselves. ${ }^{46}$ As such, the 'Statement' was not merely a simple announcement but a legally binding agreement. Thus, by avoiding

\footnotetext{
${ }^{39}$ Ike Toygür and Melih Özsöz, "Stormy months on the Aegean: the refugee deal and its impact on EU-Turkey relations," Real Instituto Elcano, March 15, 2016,

http://www.realinstitutoelcano.org/wps/portal/rielcano_en/contenido?WCM_GLOBAL_CONTEXT=/elcano/elc ano_in/zonas_in/ari27-2016-toygur-ozsoz-stormy-months-aegean-refugee-deal-impact-turkey-eu-relations.

${ }^{40}$ Zaid Hydari, "Understanding the EU-Turkey Deal," Huffington Post, November 4, 2016, http://www.huffingtonpost.com/zaid-hydari/understanding-the-eu-turk_b_9661472.html.

41 "Back to Schengen: Commission recommends phasing out of temporary border controls over next six months," Press Release 2 May 2017, accessed 29 June 2017, http://europa.eu/rapid/press-release_IP-17-1146_en.htm. ${ }^{42}$ Mark Provera, “The EU-Turkey Deal: Analysis and Considerations,” Working Paper, Brussels: Jesuit Refugee Service Europe, 2016, accessed 29 June 2017, https://jrseurope.org/assets/Publications/File-

/JRS_Europe_EU_Turkey_Deal_policy_analysis_2016-04-30.pdf.

${ }^{43}$ Maarten den Heijer and Thomas Spijkerboer, "Is the EU-Turkey refugee and migration deal a treaty?" EU Law Analysis, April 7, 2016, http://eulawanalysis.blogspot.hk/2016/o4/is-eu-turkey-refugee-and-migrationdeal.html.

${ }^{44}$ Steve Peers, “The final EU/Turkey refugee deal: a legal assessment,” EU Law Analysis, March 18, 2016, http://eulawanalysis.blogspot.hk/2016/o3/the-final-euturkey-refugee-deal-legal.html.

${ }^{45}$ Den Heijer and Spijkerboer, "Is the EU-Turkey".

${ }^{46}$ Ibid.
} 
requesting the consent of the EP before agreeing with Turkey, the EU violated procedural rules as outlined in Article 218 of the TFEU.

From a Copenhagen School's securitisation theorem perspective, the first element of a successful securitisation, the security speech act, seems to be missing whilst the presence of the second element, the adoption of extraordinary and potentially unlawful measures, is debateable. If an argument were made that these measures were unlawful and that the audience responded positively, then we would deal with the case of a 'silent securitisation'. This happens when the securitising actors adopt extraordinary measures without having designated an issue as existential threat and without having been confronted with any substantial resistance by the audience.

\section{Audience Acceptance}

To determine whether the audience accepted and endorsed the extraordinary measures at the EU level, the target audience has to be determined. Then, the response of that audience has to be investigated.

With regards to the audience's identity, EU officials, when making public statements, usually address them to the European public. This happens because the Heads of States participating in the European Council, the ministers representing their countries in the Council and the Members of the EP, directly or indirectly, draw their legitimacy from and are accountable to the European public. It would be impossible to implement extraordinary measures if the European public did not share the same anxieties regarding the refugee crisis. If the public resisted the adoption of the proposed measures, issues of democratic legitimacy would be raised. The most accurate instrument to gauge the 'feelings' of the European public with regards to the refugee crisis would be analysis of European Parliament elections, by ascertaining the proportion of the European public that voted in favour of political parties that based their election campaigns on anti-immigration rhetoric. Unfortunately, no EP elections occurred within the time frame examined in this study. The last EP elections took place in 2014 and the next ones are expected to be conducted in 2019. Therefore, this study chiefly consults the Eurobarometer surveys to estimate the (potential) response of the public to the measures taken at the EU level to tackle the immigration challenge. The findings of the Pew Research Centre surveys are also taken into account. Eurobarometer and Pew Research Centre perform surveys relevant to migration in general and to the refugee crisis in particular.

\section{A Eurobarometer}

Eurobarometer is a series of public opinion surveys conducted on behalf of the European Commission. These surveys address a wide variety of issues. For the present study, the study of the Standard Eurobarometer, which is conducted twice annually, is more relevant. Although Eurobarometer does not directly address the migrationterrorism-security nexus, a series of relevant questions could add value to the findings of this study. One of these questions investigates the feelings of the EU citizens towards immigrants who come from outside the European Union. As demonstrated in Figure 1, surveys conducted around November 2015 found that 59\% of the European public 
shared negative feelings about immigration coming from outside the Union. ${ }^{47}$ At the same time, immigration in general (58\%) and terrorism (25\%) were the main concerns of Europeans. ${ }^{48}$ What is noteworthy is that immigration as a major concern rose by 20\% since spring 2015. Fear of terrorism also increased by 8\%. Spring 2016 found the concerns about immigration decreased by $10 \%$ (48\%) while terrorism as a topic of concern, in the aftermath of the Brussels bombings, had risen by $14 \%$ (39\%) from autumn 2015. ${ }^{49}$ This positioning had not changed several months later. Forty-five percent considered immigration as the most important issue faced by the EU while terrorism followed at $32 \% .{ }^{50}$ The negativity regarding immigration of people from outside the EU remained stable (58\% in spring 2016 and 56\% in autumn 2016).

Figure 1. Concerns and feelings of the European Public

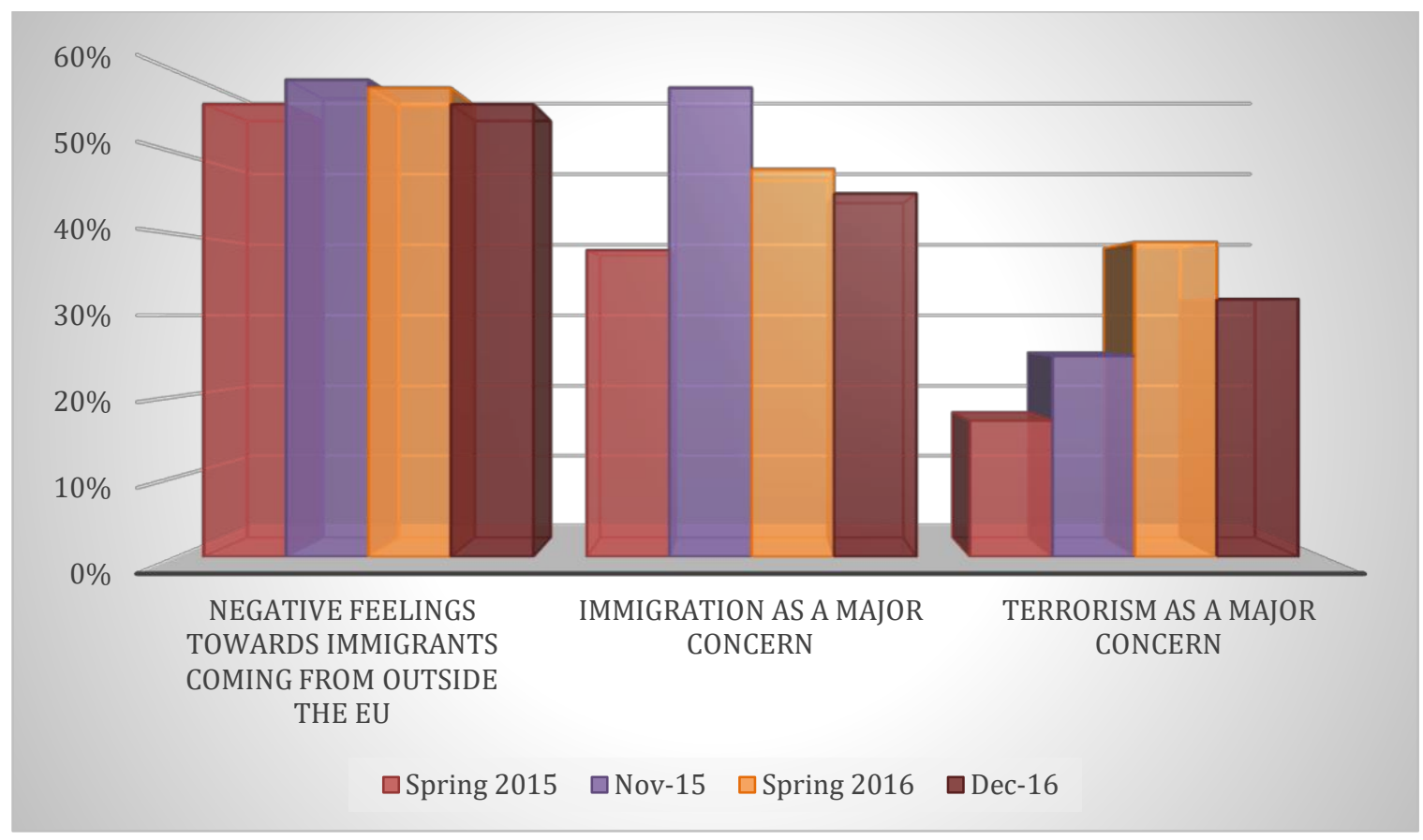

Source: Author's own compilation of Eurobarometer surveys

A special survey conducted by the European Commission in March 2015 could be also relevant for the purposes of this study although it was performed before the Paris attacks. The Special Eurobarometer 2015 investigated the attitudes of the European public towards security. Terrorism was seen as the most important security challenge (49\%) with $92 \%$ of Europeans considering it as an essential internal security threat. ${ }^{51}$

\footnotetext{
47 “Standard Eurobarometer 84, December 2015," European Commission, accessed 29 June 2017, http://ec.europa.eu/commfrontoffice/publicopinion/index.cfm/Survey/getSurveyDetail/instruments/STANDARD/survey $\mathrm{Ky} / 2098$.

48 Ibid.

49 "Standard Eurobarometer 85, May 2016," European Commission, accessed 29 June 2017, http://ec.europa.eu/commfrontoffice/publicopinion/index.cfm/Survey/getSurveyDetail/instruments/STANDARD/surveyKy/2130. 50 "Standard Eurobarometer 86, December 2016," European Commission, accessed 29 June 2017, http://ec.europa.eu/commfrontoffice/publicopinion/index.cfm/Survey/getSurveyDetail/instruments/STANDAR D/surveyKy/2137.

51 "Special Eurobarometer 432, March 2015," European Commission, accessed 29 June 29 2017, http://ec.europa.eu/commfrontoffice/publicopinion/index.cfm/Survey/getSurveyDetail/instruments/SPECIAL/surveyKy/ 2085 .
} 
Immigration, and in particular irregular immigration, was viewed as one of the most crucial security challenges by only $19 \%$ of respondents. ${ }^{52}$

Although the Eurobarometer surveys do not directly ask the interviewees' opinions about the measures taken at the EU level to deal with the refugee crisis, these surveys could provide an indication whether the European public would support the adopted measures.

The asylum seekers in their entirety are non-EU nationals. A public of which $58 \%$ to $59 \%$ appears to be sceptical towards immigrants from outside the EU is very likely to support any measures that would curb the numbers of third-country nationals present in the EU. Moreover, a public of which more than the $50 \%$ considers immigration as the most important issue faced by the EU is also very likely to accept the measures taken by the EU even when such measures are potentially unlawful. Nineteen percent of the European public considered immigration as the most crucial security challenge in March 2015, before one million asylum seekers crossed the EU borders, and before the asylum seekers were blamed for the series of terrorist attacks across Europe. The findings of the Special Eurobarometer 2015 would be substantially different if the survey had been conducted one year later. The findings of the Pew Research Centre survey of September 2016 confirm these thoughts.

\section{B Pew Research Centre}

The Pew Research Centre (PRC) conducted surveys that, although it did not cover all of the EU member states, showed to a large extent the perceptions of Europeans about immigration. The PRC surveys are particularly relevant to this study due to the specificity of the questions. A survey published in September 2016 found that $59 \%$ of Europeans across ten Member States were concerned that the influx of refugees would increase the likelihood of terrorism and 50\% voiced concern that refugees were a burden to their countries. ${ }^{53}$ Regarding the connection between the refugee crisis and insecurity, 50.6\% of Europeans from the ten Member States believed that a large number of refugees leaving Iraq and Syria constituted a significant threat to their country. ${ }^{54}$

Apparently, the refugee influx and terrorism constituted the major concerns of the European public. A high proportion of European citizens saw refugees as potential terrorists. Almost six out of ten Europeans feared that refugees were related to the terrorist attacks. A slight majority of the EU public (50.6\%) perceived the asylum seekers as significant threats.

The findings of the Eurobarometer and the PRC surveys demonstrate that immigration and terrorism constitute the primary concerns of the European public. The majority of this public considers refugees as a potential terrorist threat and as a burden to their country. Taking into account the high degree of negativity, scepticism and fear of Europeans towards immigrants and refugees in particular, it is safe to conclude that the European public would accept any emergency and illegitimate measures taken by the Union to deal with the crisis.

\footnotetext{
$5^{2}$ Ibid.

${ }^{53}$ Jacob Poushter, "European opinions of the refugee crisis in 5 charts," Pew Research Center, September 16, 2016, http://www.pewresearch.org/fact-tank/2016/o9/16/european-opinions-of-the-refugee-crisis-in-5-charts/. ${ }^{54}$ Ibid.
} 
To sum up, even though no acts or officially unlawful security measures have been detected at the EU level, if one takes into consideration the negative predisposition of the majority of the EU public towards immigration, it is possible to conclude that the adoption and implementation of any potential securitisation measures would be an easy task for any securitising actor at the EU level.

\section{Concluding Remarks}

This study, by employing the Copenhagen School's analytical framework assessed the extent to which immigration at the EU level has been succesfully securitised after the terrorist attacks in Paris. Apart from merely examining the existence of security speech acts and the lawfulness of the emergency measures as is usually performed by the current securitisation literature, this study investigated the actual or potential response of the target audience to the securitisation moves. The outcomes of this investigation suggest that even after the terrorist attacks across Europe, migration has not been succesfuly securitised at the EU level.

Despite the fact that the European Council and the Commission, as well as their most prominent leaders, have repeatedly alarmed their audience, the European public, by invoking the 'dangers' inherent in the immigration crisis, they never presented the refugee crisis as an existential threat to the EU. Two of the emergency measures that were employed by the EU, the EBCG Regulation and the EU-Turkey 'Statement', were examined from a legal point of view. It was found that both measures were procedurally atypical and potentially unlawful. Yet, until a court officially declares these measures unlawful, they will be considered legitimate and will not fall within the meaning of emergency and illegitimate measures as defined by the theorists of the Copenhagen School. Further, the investigation of the 'beliefs' of the EU public about migration revealed that its majority is negatively predisposed towards immigration from outside the EU and suggested that this negative predisposition would render a potential securitisation attempt successful.

This study has also highlighted that all components of a succesful securitisation should be studied by scholars employing the analytical framework of Buzan, Wæver and de Wilde (1998). The audience acceptance element is equally important to the security speech acts and the emergency measures. As such, it should not be left aside by future securitisation studies. However, not only the study but also the theorisation of the audience acceptance component is absent from the current literature. A more detailed analysis and theorisation of that component would add value to the Copenhagen School's analytical framework and would foster a better understanding of securitisations not only of migration but also of other non-traditional security issues.

\section{Bibliography}

Adamson, Fiona. "Crossing Borders: International Migration and National Security." International Security 3, no. 1 (summer 2006): 165-199.

Baume, de la Maia. “Donald Tusk says EU migration crisis is 'never-ending.” Politico, April 13, 2016. http://www.politico.eu/article/donald-tusk-says-eu-migration-crisisis-never-ending/. 
Benam, Çiğdem. "Emergence of a "Big Brother" in Europe: Border Control and Securitization of Migration." Insight Turkey 13, no. 3 (2011): 191-207.

Bogdan, Ioan, Maria Claudia Mera, and Florin Ioan Oroian. "Determinations and Conditionality in the Context of the Migration in the European Union." Eurolimes 18, (2014): 111-126.

Boswell, Christina. "Migration Control in Europe after 9/11: Explaining the Absence of Securitization.” Journal of Common Market Studies 45, no. 3 (2007): 589-610.

Buzan, Barry, Ole Waever, and Jaap de Wilde. Security a new framework for analysis. Boulder, Colo.: Lynne Rienner, 1998.

Campesi, Giuseppe. "The Arab Spring and the Crisis of the European Border Regime: Manufacturing Emergency in the Lampedusa Crisis.” EUI Working Paper RSCAS 2011/59, (2011).

Carrera, Sergio and Leonhard Den Hertog. "A European Border and Coast Guard: What's in a name?” CEPS Paper in Liberty and Security in Europe, no. 88 (2016).

Day, Kate. "Donald Tusk calls for 18-month screening of refugees." Politico, December 3, 2015. http://www.politico.eu/article/donald-tusk-calls-18-monthscreening-of-refugees-migration-merkel-greece-italy/.

European Commission. "Special Eurobarometer 432.” March 2015. http://ec.europa.eu/commfrontoffice/publicopinion/index.cfm/Survey/getSurveyDe tail/instruments/SPECIAL/surveyKy/2085.

European Commission. "Standard Eurobarometer 84." December 2015. http://ec.europa.eu/commfrontoffice/publicopinion/index.cfm/Survey/getSurveyDe tail/instruments/STANDARD/surveyKy/2098.

European Commission. "Standard Eurobarometer 85." May 2016. http://ec.europa.eu/commfrontoffice/publicopinion/index.cfm/Survey/getSurveyDe tail/instruments/STANDARD/surveyKy/2130.

European Commission. "Standard Eurobarometer 86.” December 2016. http://ec.europa.eu/commfrontoffice/publicopinion/index.cfm/Survey/getSurveyDe tail/instruments/STANDARD/surveyKy/2137.

European Union. "Consolidated version of the Treaty on the Functioning of the European Union, 2008/C 115/o1.” 13 December 2007. Accessed June 29, 2017. http://eur-lex.europa.eu/legalcontent/EN/TXT/?uri=OJ\%3AC\%3A2008\%3A115\%3ATOC.

Ferraro, Francesca and Emilio de Capitani. "The new European Border and Coast Guard: yet another "half way" EU reform?" ERA Forum 17, no.3 (2016): 385-398.

Glover, Robert. "The Theorist and the Practitioner: Linking the Securitization of Migration to Activist Counter-Narratives." Geopolitics, History and International Relations 3, no.1 (2011). 
Hale, Virginia. "EU chief: Borders must stay open despite deadly terror attacks.” Breibart, December 24, 2016.

http://www.breitbart.com/london/2016/12/24/eu-chief-borders-must-stay-open/.

Heijer, den Maarten and Thomas Spijkerboer. "Is the EU-Turkey refugee and migration deal a treaty?” EU Law Analysis, April7, 2016. http://eulawanalysis.blogspot.hk/2016/o4/is-eu-turkey-refugee-and-migration-deal.html.

Huysmans, Jef. The Politics of Insecurity: Fear, Migration and Asylum in the EU. London, UK: Routledge, 2006.

Hydari, Zaid. "Understanding the EU-Turkey Deal." Huffington Post, November 4, 2016. http://www.huffingtonpost.com/zaid-hydari/understanding-the-euturk_b_9661472.html.

Iancu, Nicolaie and Elena-Ana Nechita. "Debates and Controversies on European Migration Policies.” Law Review 8, no. 2 (December 2018).

Karyotis, Georgios and Dimitris Skleparis. "Resistance to the Criminalization of Migration.” In The Immigrant Other: Lived Experiences in a Transnational World, edited by Rich Furman, Greg Lamphear, and Douglas Epps, 266- 282. New York, NY: Columbia University Press, 2016.

Karyotis, Georgios and Stratos Patrikios. "Religion, Securitization and Antiimmigration Attitudes: The Case of Greece.” Journal of Peace Research 47, no. 1 (2010): 43-57.

Karyotis, Georgios. "Securitization of Migration in Greece: Process, Motives and Implications.” International Political Sociology 6, (2012): 390-408.

Maurice, Eric. "Tusk sets EU two-month deadline on migrant crisis.” EUobserver, January 19, 2016. https://euobserver.com/migration/131905.

Maurice, Eric. "Tusk: 'Wave of migrants too big not to be stopped'." EUobserver, December 3, 2015. https://euobserver.com/migration/131363.

Peers, Steve. "The final EU/Turkey refugee deal: a legal assessment." EU Law Analysis, March 18, 2016. http://eulawanalysis.blogspot.hk/2016/o3/the-finaleuturkey-refugee-deal-legal.html.

Poushter, Jacob. "European opinions of the refugee crisis in 5 charts." Pew Research Center, September 16, 2016. http://www.pewresearch.org/facttank/2016/o9/16/european-opinions-of-the-refugee-crisis-in-5-charts/.

Press Release 2 May 2017. "Back to Schengen: Commission recommends phasing out of temporary border controls over next six months.” Accessed June 29, 2017. http://europa.eu/rapid/press-release_IP-17-1146_en.htm.

Press Release 3 February 2017. "Remarks by President Donald Tusk at the informal summit in Malta.” Accessed June 29, 2017.

http://www.consilium.europa.eu/en/press/press-releases/2017/o2/o3-tusk-pressremarks-malta/. 
Press Release 4 March 2016. "Back to Schengen: Commission proposes Roadmap for restoring fully functioning Schengen system.” Accessed June 29, 2017. http://europa.eu/rapid/press-release_IP-16-585_en.htm.

Press Release 6 October 2016. "Securing Europe's external borders: Launch of the European Border and Coast Guard Agency.” Accessed June 19, 2017. http://europa.eu/rapid/press-release_IP-16-3281_en.htm.

Press Release 15 December 2015. "A European Border and Coast Guard to protect Europe's External Borders.” Accessed June 29, 2017. http://europa.eu/rapid/pressrelease_IP-15-6327_en.htm.

Press Release 16 November 2015. "Paris attacks: the European Union stands united." Accessed June 29, 2017. http://europa.eu/rapid/press-release_AC-16-1970_en.htm.

Press Release 16 September 2016. "Remarks by President Donald Tusk after the Bratislava summit.” Accessed June 29, 2017. http://www.consilium.europa.eu/en/press/press-releases/2016/o9/16-tusk-final-remarks-bratislava/.

Press Release 18 March 2016. "European Council Meeting Conclusions.” Accessed June 29, 2017. http://www.consilium.europa.eu/en/press/pressreleases/2016/o3/18-european-council-conclusions/.

Press Release 18 March 2016. "EU-Turkey Statement.” Accessed June 29, 2017. http://www.consilium.europa.eu/en/press/press-releases/2016/o3/18-eu-turkeystatement/.

Press Release 21 October 2016. "European Council Meeting Conclusions." Accessed June 29, 2017. http://www.consilium.europa.eu/en/press/pressreleases/2016/10/21-european-council-conclusions/.

Press Release 25 October 2016. "Commission recommends extending temporary internal border controls for a limited period of three months." Accessed June 29, 2017. http://europa.eu/rapid/press-release_IP-16-3501_en.htm.

Press Release 28 June 2016. "European Council Meeting Conclusions.” Accessed June 29, 2017. http://www.consilium.europa.eu/en/press/pressreleases/2016/o6/28-euco-conclusions/.

Press Release 31 January 2017. "Invitation letter from President Donald Tusk to the EU heads of state or government before Malta summit.” Accessed June 29, 2017. http://www.consilium.europa.eu/en/press/press-releases/2017/o1/31-tuskinvitation-letter-malta/.

Provera, Mark. “The EU-Turkey Deal: Analysis and Considerations.” Working Paper, Brussels: Jesuit Refugee Service Europe (2016). Accessed June 29, 2017. https://jrseurope.org/assets/Publications/File/JRS_Europe_EU_Turkey_Deal_poli cy_analysis_2016-04-30.pdf.

Rankin, Jennifer. "Do not come to Europe, Donald Tusk warns economic migrants." The Guardian, March 3, 2016. 
https://www.theguardian.com/world/2016/mar/o3/donald-tusk-economicmigrants-do-not-come-to-europe.

Rutter, Tamsin. "EU risks being shaken apart by refugee crisis, warns Brussels." The Guardian, December 4, 2015. https://www.theguardian.com/public-leadersnetwork/2015/dec/04/european-union-values-shaken-refugee-crisis.

Taureck, Rita. "Securitization Theory and Securitization Studies." Journal of International Relations and Development 9, no. 1 (2006): 53-61.

Toygür, Ike and Melih Özsöz. "Stormy months on the Aegean: the refugee deal and its impact on EU-Turkey relations.” Real Instituto Elcano, March 15, 2016.

http://www.realinstitutoelcano.org/wps/portal/rielcano_en/contenido?WCM_GLO BAL_CONTEXT=/elcano/elcano_in/zonas_in/ari27-2016-toygur-ozsoz-stormymonths-aegean-refugee-deal-impact-turkey-eu-relations.

Watson, Scott. "Framing' the Copenhagen School: Integrating the Literature on Threat Construction." Millennium: Journal of International Studies 40, no. 2 (2011): 279-301.

Winneker, Graig. “Tusk: EU needs ‘tough' migration policies.” Politico, April 22, 2016. http://www.politico.eu/article/donald-tusk-eu-needs-tough-migrationpolicies/.

Worley, Will. "Six out of 10 migrants to Europe come for 'economic reasons' and are not refugees, EU Vice President Frans Timmermans says." Independent, January 27, 2016. http://www.independent.co.uk/news/world/europe/six-out-of-10-migrantsto-europe-come-for-economic-reasons-and-are-not-refugees-eu-vice-presidenta6836306.htm. 